\title{
Development of a Power Electronics Controller for the Advanced Stirling Radioisotope Generator
}

Douglas K. Leland and Joel F. Priest

Lockheed Martin, Denver, Colorado

Douglas E. Keiter

Sunpower Incorporated, Athens, Ohio

Jeffrey G. Schreiber

Glenn Research Center, Cleveland, Ohio 


\section{NASA STI Program . . . in Profile}

Since its founding, NASA has been dedicated to the advancement of aeronautics and space science. The NASA Scientific and Technical Information (STI) program plays a key part in helping NASA maintain this important role.

The NASA STI Program operates under the auspices of the Agency Chief Information Officer. It collects, organizes, provides for archiving, and disseminates NASA's STI. The NASA STI program provides access to the NASA Aeronautics and Space Database and its public interface, the NASA Technical Reports Server, thus providing one of the largest collections of aeronautical and space science STI in the world. Results are published in both non-NASA channels and by NASA in the NASA STI Report Series, which includes the following report types:

- TECHNICAL PUBLICATION. Reports of completed research or a major significant phase of research that present the results of NASA programs and include extensive data or theoretical analysis. Includes compilations of significant scientific and technical data and information deemed to be of continuing reference value. NASA counterpart of peer-reviewed formal professional papers but has less stringent limitations on manuscript length and extent of graphic presentations.

- TECHNICAL MEMORANDUM. Scientific and technical findings that are preliminary or of specialized interest, e.g., quick release reports, working papers, and bibliographies that contain minimal annotation. Does not contain extensive analysis.

- CONTRACTOR REPORT. Scientific and technical findings by NASA-sponsored contractors and grantees.

- CONFERENCE PUBLICATION. Collected papers from scientific and technical conferences, symposia, seminars, or other meetings sponsored or cosponsored by NASA.

- SPECIAL PUBLICATION. Scientific, technical, or historical information from NASA programs, projects, and missions, often concerned with subjects having substantial public interest.

- TECHNICAL TRANSLATION. Englishlanguage translations of foreign scientific and technical material pertinent to NASA's mission.

Specialized services also include creating custom thesauri, building customized databases, organizing and publishing research results.

For more information about the NASA STI program, see the following:

- Access the NASA STI program home page at http://www.sti.nasa.gov

- E-mail your question via the Internet to help@ sti.nasa.gov

- Fax your question to the NASA STI Help Desk at 301-621-0134

- Telephone the NASA STI Help Desk at 301-621-0390

- Write to: NASA Center for AeroSpace Information (CASI) 7115 Standard Drive Hanover, MD 21076-1320 
NASA/TM-2008-215031

AIAA-2007-4737

\section{Development of a Power Electronics Controller for the Advanced Stirling Radioisotope Generator}

Douglas K. Leland and Joel F. Priest

Lockheed Martin, Denver, Colorado

Douglas E. Keiter

Sunpower Incorporated, Athens, Ohio

Jeffrey G. Schreiber

Glenn Research Center, Cleveland, Ohio

Prepared for the

Fifth International Energy Conversion Engineering Conference and Exhibit

sponsored by the American Institute of Aeronautics and Astronautics

St. Louis, Missouri, June 25-27, 2007

National Aeronautics and

Space Administration

Glenn Research Center

Cleveland, Ohio 44135 
This report contains preliminary findings, subject to revision as analysis proceeds.

Trade names and trademarks are used in this report for identification only. Their usage does not constitute an official endorsement, either expressed or implied, by the National Aeronautics and Space Administration.

Level of Review: This material has been technically reviewed by technical management.

Available from

NASA Center for Aerospace Information 7115 Standard Drive

Hanover, MD 21076-1320
National Technical Information Service 5285 Port Royal Road Springfield, VA 22161 


\title{
Development of a Power Electronics Controller for the Advanced Stirling Radioisotope Generator
}

\author{
Douglas K. Leland and Joel F. Priest \\ Lockheed Martin \\ Denver, Colorado 80201 \\ Douglas E. Keiter \\ Sunpower Incorporated \\ Athens, Ohio 45701 \\ Jeffrey G. Schreiber \\ National Aeronautics and Space Administration \\ Glenn Research Center \\ Cleveland, Ohio 44135
}

\begin{abstract}
Under a U.S. Department of Energy program for radioisotope power systems, Lockheed Martin is developing an Engineering Unit of the Advanced Stirling Radioisotope Generator (ASRG). This is an advanced version of the previously reported SRG110 generator. The ASRG uses Advanced Stirling Convertors (ASCs) developed by Sunpower Incorporated under a NASA Research Announcement contract. The ASRG makes use of a Stirling controller based on power electronics that eliminates the tuning capacitors. The power electronics controller synchronizes dual-opposed convertors and maintains a fixed frequency operating point. The controller is single-fault tolerant and uses high-frequency pulse width modulation to create the sinusoidal currents that are nearly in phase with the piston velocity, eliminating the need for large series tuning capacitors. Sunpower supports this effort through an extension of their controller development intended for other applications. Glenn Research Center (GRC) supports this effort through system dynamic modeling, analysis and test support. The ASRG design arrived at a new baseline based on a system-level trade study and extensive feedback from mission planners on the necessity of single-fault tolerance. This paper presents the baseline design with an emphasis on the power electronics controller detailed design concept that will meet space mission requirements including single fault tolerance.
\end{abstract}

\section{Nomenclature}

$\begin{array}{ll}\text { APFC } & \text { Active Power Factor Control } \\ \text { ASC } & \text { Advanced Stirling Convertor } \\ \text { ASRG } & \text { Advanced Stirling Radioisotope Generator } \\ \text { DSP } & \text { Digital Signal Processing } \\ \text { EMC } & \text { Electro Magnetic Compatibility } \\ \text { EMI } & \text { Electro Magnetic Interference } \\ \text { EU } & \text { Engineering Unit } \\ \text { FLDT } & \text { Fast Linear Displacement Transducer } \\ \text { FMECA } & \text { Failure Modes, Effects and Criticality Analysis } \\ \text { FPGA } & \text { Field Programmable Gate Array } \\ \text { FPSC } & \text { Free-Piston Stirling Convertor } \\ \text { FTB } & \text { Frequency Test Bed } \\ \text { GPHS } & \text { General Purpose Heat Source } \\ \text { GRC } & \text { NASA Glenn Research Center }\end{array}$




$\begin{array}{ll}\text { LMSS } & \text { Lockheed Martin Space Systems } \\ \text { PI } & \text { Proportional/Integral } \\ \text { PSA } & \text { Parts Stress Analysis } \\ \text { PWM } & \text { Pulse Width Modulation } \\ \text { VHDL } & \text { Very High Design Language } \\ \text { WCA } & \text { Worst Case Analysis }\end{array}$

\section{Introduction}

Under a U.S. Department of Energy program for radioisotope power systems, Lockheed Martin Space Systems Company (LMSS) is developing an Engineering Unit (EU) of the Advanced Stirling Radioisotope Generator (ref. 1). The ASRG will use two Advanced Stirling Convertors (ASCs) developed by Sunpower Incorporated under a NASA Research Announcement contract managed by Glenn Research Center (GRC). GRC also provides a supporting role in this effort through system dynamic modeling and analysis, and test support. ASRG will make use of an ASC controller based on power electronics that eliminate tuning capacitors by utilizing nondissipative control methods. The power electronics controller will synchronize dual-opposed convertors and maintain a fixed frequency operating point.

The ASC is a closed-cycle, reversible heat engine which converts heat from any external source into mechanical work by moving a volume of gas between a hot acceptor and a cold rejector. The resulting oscillating pressure wave causes an appropriately sprung piston to oscillate sinusoidally with a linear motion. The piston, in turn, forms the part of a linear alternator that converts the mechanical work into ac power.

The EU controller will be designed to meet the form, fit, and function of a fully qualified flight unit but will be built with nonflight components. A complete worst case analysis (WCA), parts stress analysis (PSA), and failure modes, effects and criticality analysis (FMECA) will be performed assuming flight qualified parts and mission environment.

Historically, LMSS has been involved with interplanetary missions from the Viking I and II expeditions in the 1970s to the present Mars Reconnaissance Orbiter. LMSS has designed and qualified spacecraft avionics from Command and Data Handling subsystems to Electrical Power subsystems. Combining this expertise with Sunpower and GRC, who are in the forefront of Stirling technology advancement, has allowed us to develop a space-qualifiable controller design for ASRG to meet future NASA mission needs. This nondissipative controller design was initially developed by Sunpower Inc. and is being implemented in the LMSS controller algorithm that also includes typical spacecraft interfaces for power bus, telemetry and command. This algorithm has been extensively simulated with an ASC model that was developed by GRC in the Simplorer environment.

This paper presents ASC and the nondissipative controller designs; associated control method, modeling, simulation, and testing results to date.

\section{Free-Piston Stirling Convertor}

An ASC is a free-piston Stirling cycle engine that has been integrated with a linear alternator. The term convertor is used to describe the integrated unit that converts thermal energy to electrical power. The free-piston Stirling engine is a closed-cycle, reversible heat engine, which uses the Stirling cycle to convert heat from an external source into work. The ideal Stirling cycle is based on steps of isothermal expansion and compression, coupled with steps of constant volume heating and cooling. These steps are the result of movement of two components; the power piston, which changes the volume of the working fluid, and the displacer, which moves working fluid between the hot expansion space and the relatively cool compression space. The term free-piston is used since the oscillating motions of the two moving components are governed by the pressure wave and their spring-mass-damping characteristics. The resulting pressure wave causes the piston to oscillate sinusoidally with cycle power being extracted by a linear alternator. 
The Sunpower linear alternator is based on a configuration in which a ring of permanent magnets moves through the air gap of a stator. The stator is an assembly of laminations and a coil that is mounted to the structure and remains stationary. As the piston oscillates, the permanent magnets move through the air gap of the stator, causing current to flow in the coil of wire. The laminations provide structural support and are used to contain the magnetic fields to maximize efficiency. During steady state operation, the power coming into the face of the power piston from the thermodynamic cycle must be equal to the power extracted by the linear alternator. If these are unequal, the piston amplitude will either increase or decrease, depending on the nature of the imbalance. To ensure stable operation at a given piston amplitude, power extracted by the linear alternator must change more quickly with amplitude than thermodynamic power produced by the cycle.

The free-piston Stirling convertor that is being integrated into the ASRG EU generator has been designated as the ASC. The ASC is the product of a NASA contract awarded to Sunpower, Inc. under the Radioisotope Power Conversion Technology (RPCT) project. The starting point of the RPCT effort was a high-efficiency, low mass Stirling convertor that was developed by Sunpower under a NASA SBIR contract, designated the EE-35. The EE-35 was designed for nominal power output of $35 \mathrm{~W}_{\mathrm{e}}$, but had sufficient margin to operate well above $40 \mathrm{~W}$ output. Both of these convertors approach a specific power of $100 \mathrm{~W}_{\mathrm{e}} / \mathrm{kg}$, depending on details of the thermal interfaces and the instrumentation desired. The designs use the previously described moving-magnet linear alternator, a system of hydrostatic gas bearings for noncontacting operation of the piston and displacer, and a planar spring to resonate the displacer. The piston and displacer operate in a common cylinder such that their motions overlap, thereby reducing overall length and dead volume in the working space.

The ASC convertors for the EU generator are being fabricated with a heat collector to interface with the General Purpose Heat Source (GPHS) module heat source, a heat-conducting flange to transport waste heat to the radiator, and a Fast Linear Displacement Transducer (FLDT) to measure piston position. The convertor is shown in figure 1 and a model of the generator is shown in figure 2 .

The convertors have been designed for high reliability over a 14-year mission with up to 3 years of storage, and will be hermetically sealed to contain the helium working fluid. An early developmental unit was recently vibration tested up to $17.4 \mathrm{~g}_{\mathrm{rms}}$ to address concerns regarding launch vibration, and there are multiple units currently under extended operation test at GRC. Following assembly of the EU generator, tests will be conducted to verify compliance with requirements for performance, operation in thermal vacuum, electromagnetic emissions, and operation under launch vibration and shock. The generator will then be placed under extended operation to demonstrate life.

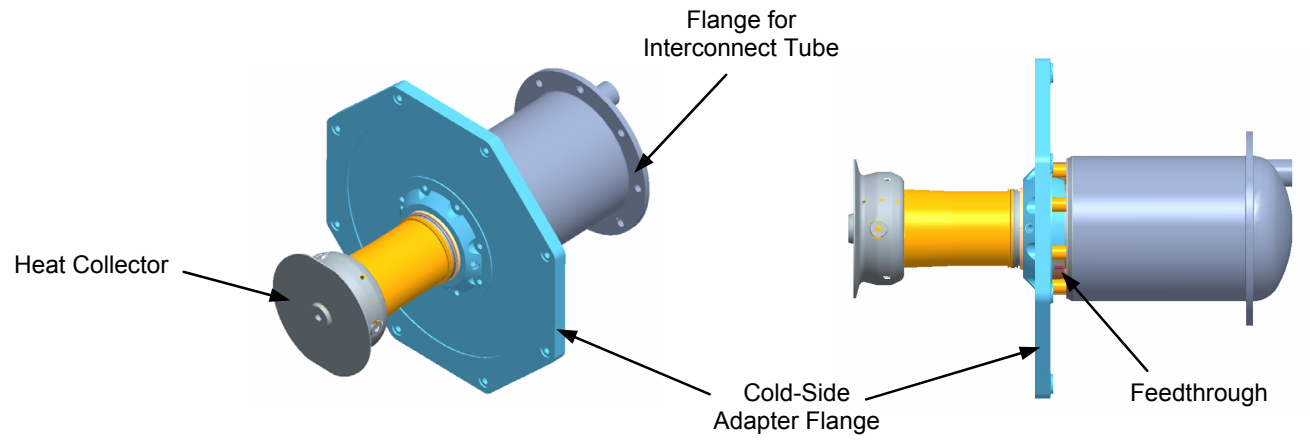

Figure 1.-ASRG convertor. 


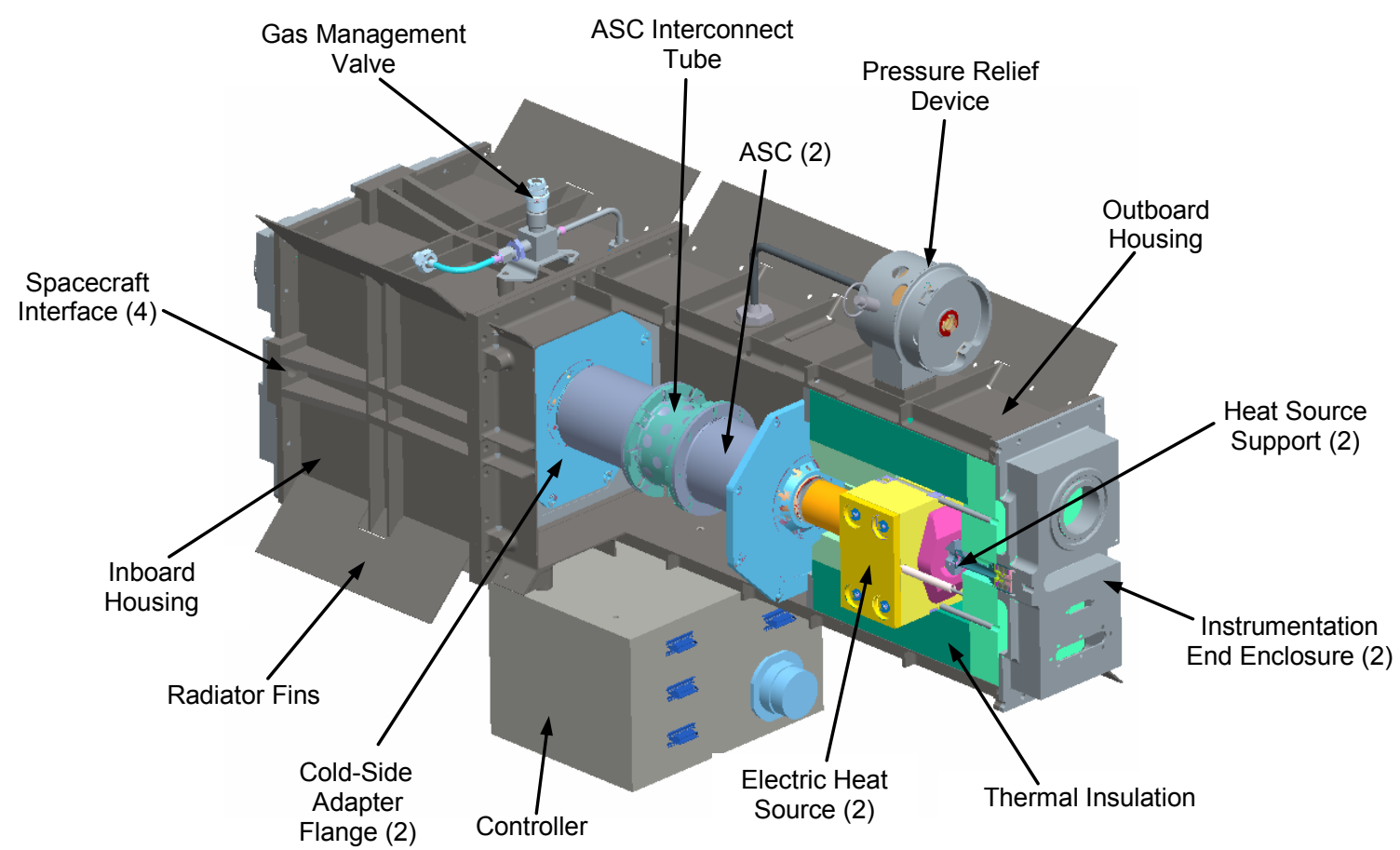

Figure 2.-ASRG generator.

\section{Nondissipative ASC Controller}

\section{Critical Functionality}

Several features of the controller design have been identified by the user community as being necessary to the integral design of a space qualified controller. The ASC controller critical functional requirements are summarized here:

- Single Point Fault (SPF) Tolerant

- Provide controller and ASC telemetry and status

- Commandable ASC hot end temperature set point

- Compatible with battery or capacitor dominated spacecraft bus with a voltage range of 22 to $36 \mathrm{~V}$.

- Space and Source Radiation TID to $126 \mathrm{Krad}(\mathrm{Si})(\mathrm{RDF}=2)$

- 17-year design life

- Controller Efficiency $>93$ percent

The controller achieves its SPF tolerance through the use of an $\mathrm{N}+1$ redundant system architecture as shown in figure 3 . Three identical controller cards make up the controller assembly. Two of the cards will be actively controlling their associated ASC, while all three cards are actively monitoring the status of the other two controllers and the ASCs. If a fault is detected in either of the active controllers, ASCs, or associated telemetry the backup controller will be switched in and autonomously assume control of the ASC. An extensive fault protection algorithm exists in each controller Field Programmable Gate Array (FPGA); if 2 of the 3 controller FPGAs agree on a fault, the fault is acted upon in accordance with the predetermined fault protection response. 


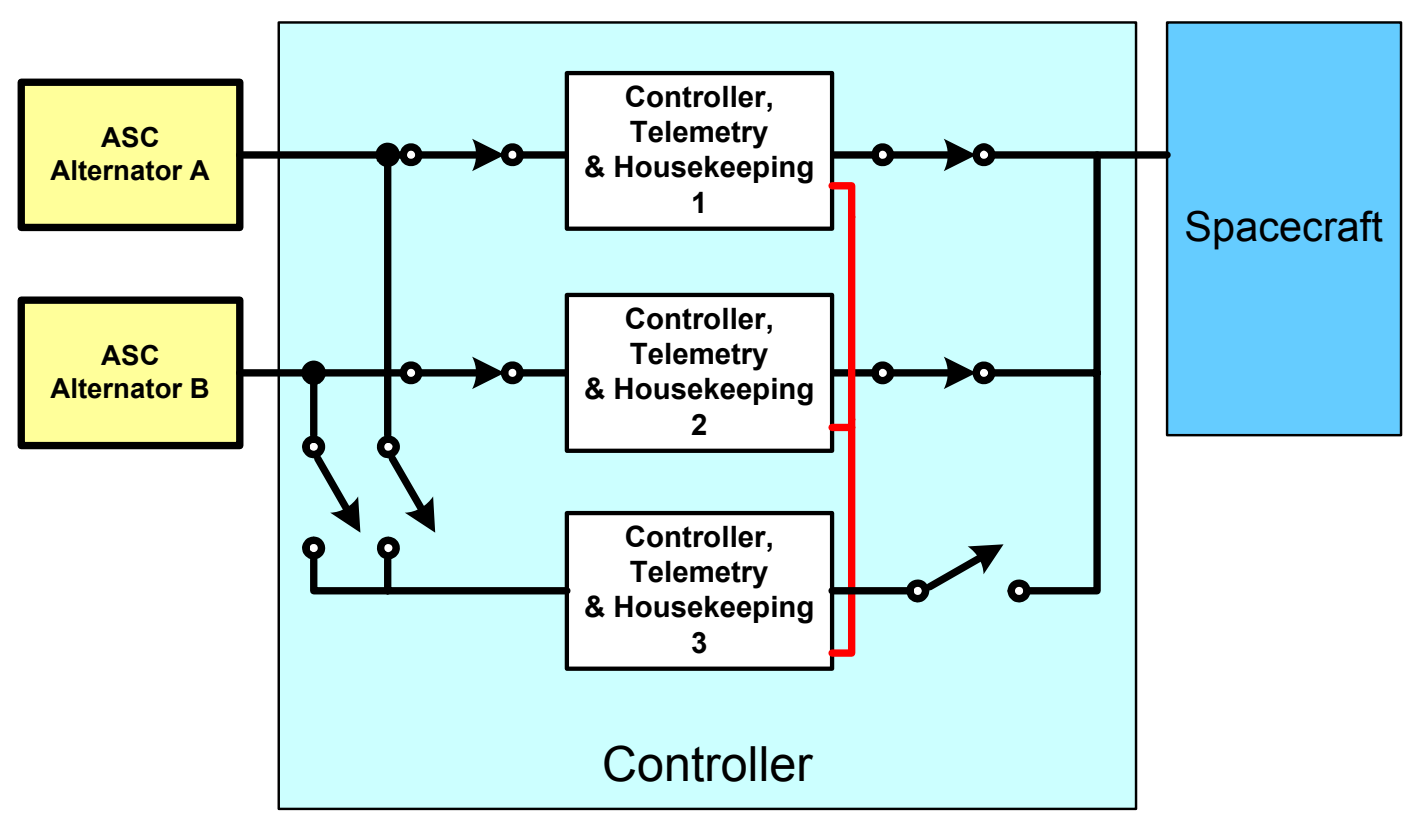

Figure 3.-Controller redundancy block diagram.

Each of the three controllers will provide the spacecraft with telemetry and status via its own RS-422 like serial bus. The ASC telemetry (hot and cold end temperature, peak piston position, and peak alternator voltage) will be digitized and sent to the spacecraft, along with the status of each controller (ASC temperature set point, fault protection status, and ASC peak piston position.) Commands to the controllers will also be sent across the serial bus. These commands consist of the hot-end temperature set point, ASC stall command, ASC restart command, and failed temperature sensor reset.

The output of the controller needs to be compatible with the typical spacecraft battery bus voltage of 22 to $36 \mathrm{~V}$, or a capacitor dominated bus with a fixed voltage "zener" bus at $28 \mathrm{~V}$. This compatibility is inherent in the H-switch design, as the output voltage is independent of the input voltage and will follow the spacecraft bus voltage automatically due to the boost nature of the H-switch. The H-switch simultaneously rectifies the alternator ac voltage and controls the alternator current without the need for an intermediate dc to dc converter, thus improving controller efficiency.

The life and radiation requirement are met via the proper parts selection. A worst case analysis (WCA) and parts stress analysis (PSA) will be completed to make sure that the parts and circuits are derated properly to meet the 17-year mission requirement. The radiation requirement is met with good radiation design practices and radiation tolerant part selection. The EU unit will contain only commercial parts but the commercial parts were chosen to match the flight-part footprint; thus alleviating a major board redesign.

Power per mass is a very critical component of the generator design with a total generator design goal of more than $7 \mathrm{~W}_{\mathrm{e}} / \mathrm{kg}$. This translates to high efficiency and low mass requirement for the controller design. Great care has been taken to increase the controller efficiency by simplifying the circuit designs, minimizing the number of components, and choosing very lower power consumption components. The calculated efficiency for the present controller design is greater than 93 percent and this includes all of the internal power consumption of the box. The current best estimate mass is at $2.55 \mathrm{~kg}$.

\section{Control Algorithm Development}

The ASRG program has changed and evolved from the previous Stirling Radioisotope Generator (SRG1 10) program. The baseline control algorithm for the SRG110 was what is referred to as Passive Power-Factor Control (PPFC); where maximum power output is achieved by using a very large capacitor 
in series with the alternator output. Control was achieved by matching the alternator output voltage to the bus voltage through an output stage Buck Regulator. This approach does not lend itself to a low mass system due to the inordinate size of the tuning capacitor.

During the SRG110 program it was determined that an Active Power Factor Control (APFC) approach would allow the mass of the controller to be reduced significantly and at the same time increase the efficiency by eliminating the need for the Buck Regulator output stage. LMSS has extensive experience in designing space qualified hardware but has very little experience in designing and developing controllers for Stirling engine systems. GRC and Sunpower both have been working on Stirling engines and controllers for some time (refs. 2 and 3). This mix of different experience base made for an ideal team that has been formed with LMSS, GRC, and Sunpower.

Reference 2 documents the history of Sunpower's controller work and evolution of the controller algorithm. This Sunpower controller work has become the baseline for the LMSS controller algorithm and design.

The Sunpower algorithm as it exists for the Army $160 \mathrm{~W}$ JP-8 fueled FPSE portable power source regulates the mid-point dc voltage at the output of the active rectifier stage to a constant voltage of approximately $55 \mathrm{Vdc}$ by modifying the ASC stroke. The mid-point voltage varies between 40 and $95 \mathrm{Vdc}$ as the ASC responds to changes in load demand. An output stage dc to dc power supply converts the mid-point voltage into constant $28 \mathrm{Vdc}$ power for the user. The Army power source includes a JP-8 burner, which functions as a variable power heat source to the ASC. The power from the heat source is modulated to maintain constant ASC hot-end temperature and to maximize efficiency independent of load demand and convertor operating conditions. The ASRG system differs from the Army Battery Charger in that it uses a constant power heat source and interfaces to a variable voltage bus. The ASRG algorithm and design have adopted some pieces of Army Battery Charger design but have changed others in order to control the ASCs in the ASRG system environment. The major differences between the Army Battery Charger system and ASRG system are outlined in table 1.

TABLE 1.-SUNPOWER/LMSS DESIGN COMPARISON

\begin{tabular}{|c|c|}
\hline Sunpower & LMSS \\
\hline Variable power heat source & Constant power heat source \\
\hline Variable generator power output & $\begin{array}{l}\text { Constant Generator power output } \\
\text { Requires bus controller to use } 100 \text { percent of available power }\end{array}$ \\
\hline Regulated 28 Vdc generator output & $\begin{array}{l}\text { Generator output voltage determined by user } \\
\text { Battery/battery charger } 22 \text { to } 36 \mathrm{~V} \\
\text { Battery dominated energy storage } \\
\text { Active shunt regulator } 28 \pm 2 \mathrm{Vdc} \\
\text { Capacitor dominated energy storage }\end{array}$ \\
\hline Regulated ac voltage to alternator & Regulated ac voltage to alternator \\
\hline Two stage ac to dc power conversion & Single stage ac to dc power conversion \\
\hline Variable power load & Constant voltage load \\
\hline $\begin{array}{l}\text { Alternator/generator output power determined by: } \\
\text { - Variable power heat source } \\
\text { - Stirling convertor temperatures } \\
\text { - Piston stroke }\end{array}$ & $\begin{array}{l}\text { - ASC output power determined by constant power heat } \\
\text { source and ASC temperatures } \\
\text { - Generator power determined by temperature control loop } \\
\text { with piston stroke limiting } \\
\text { - Hot end temperature regulated by controller }\end{array}$ \\
\hline $\begin{array}{l}\text { Mid-point dc voltage feedback to modulate piston stroke } \\
\text { command } \\
\text { FLDT peak position provides stroke feedback }\end{array}$ & $\begin{array}{l}\text { FLDT peak position used to control alternator piston stroke } \\
\text { open loop voltage control mode utilized if FLDT fails }\end{array}$ \\
\hline $\begin{array}{l}\text { Microcontroller/Software implements fixed point PI } \\
\text { control loop }\end{array}$ & FPGA DSP implements fixed point PI control loop \\
\hline One frequency reference for synchronization & $\begin{array}{l}\text { Synchronization } \\
\text { Synchronization pulse } \\
\text { Simplifies single fault tolerance }\end{array}$ \\
\hline $20 \mathrm{kHz}$ PWM ac to dc boost power stage & $20 \mathrm{kHz}$ PWM ac to dc boost power stage \\
\hline
\end{tabular}




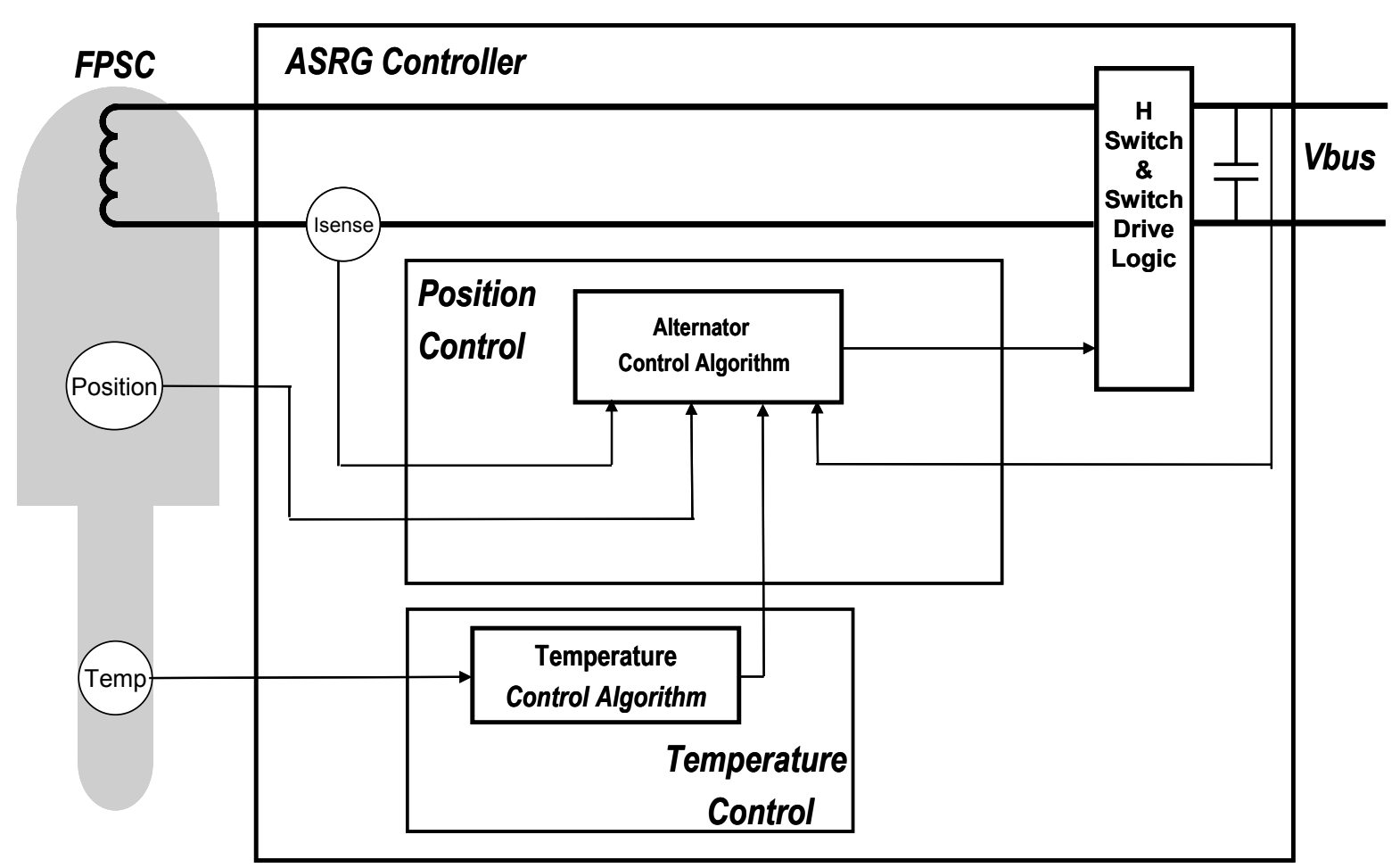

Figure 4.-ASRG algorithm block diagram.

The alternator voltage control algorithm developed by Sunpower is at the heart of the ASRG control algorithm, see figure 4. A peak piston position set point is determined from the ASC design characteristics; the algorithm then uses the set point as the nominal operating point for control of the ASC. The feedback from the FLDT sensor will be used to close the position control loop and servo the error between the set point and FLDT position to zero. The temperature control loop will be used to modify the nominal peak piston position set point to allow the ASC hot end temperature to be maintained at the temperature set point. If the temperature is above the temperature set point then a longer piston stroke will be commanded to cool the ASC; if the temperature is below the set point then a shorter piston stroke will be commanded. With the Position control and Temperature control loops set up in this manner there is no concern about instabilities occurring because there is no interaction between the loops.

The H-Switch serves a dual purpose in this design as it operates in both a boost operation as modulated by the Pulse Width Modulator (PWM) to maintain the output voltage at the correct bus voltage, and as a sine wave generator to control the ASC to the correct phase, frequency and amplitude.

\section{Controller Algorithm Simulation}

In order to verify the operation of the algorithm, it is simulated at various points throughout the algorithm and FPGA design process. One of the most critical pieces of the simulation is the ASC model; without an accurate, validated model the simulation process is worthless. GRC is using Simplorer to develop a very accurate model of the ASCs.

The System Dynamic Model (SDM) was developed at GRC and has been used for controller development efforts by GRC, LM, and Sunpower. The SDM model is capable of including the nonlinear aspects of the thermodynamics, the spring/mass/damper dynamics, the linear alternator, and the controller. The SDM model can include details such as the nonlinear characteristics of the support structure or specific electrical components by part number if this level of accuracy is required. However, there is a trade in operation of the model as details are added in that the simulation time can significantly 
grow as more details are included. Single convertors, or a pair of convertors in the dual opposed configuration can be simulated. The model is a time-domain model containing sub-cycle dynamics, allowing it to simulate the detailed transient behavior and dynamic phenomena. While the model has many nonlinear aspects included, it was created with a simplified representation of the thermodynamics based on the Schmidt analysis of the Stirling cycle. The Schmidt analysis assumes isothermal volumes in the expansion space, the heater, the cooler, and the compression space. Versions of the model were created with isothermal and with adiabatic expansion and compression, however, the cycle that exists in hardware is neither. An interface was developed at GRC that allows SDM to interface with the Sage Stirling cycle thermodynamic code if improved accuracy of the cycle is required. With this feature, SDM and Sage iterate to arrive at a common solution of motions and thermodynamic power, however, once again, the simulation time is significantly extended. The SDM has been described in Reference 4 along with examples of its use.

Models of the Sunpower $80 \mathrm{~W}_{\mathrm{e}}$ class Frequency Test Bed (FTB) convertors and the ASCs were created in SDM. Data from FTB tests was used to validate the convertor models. Some parameters are known in detail, such as mass of moving components, however other characteristics are not known in detail and may be varied slightly to calibrate the model. One example is damping provided by flow losses through heat exchangers under oscillating flow conditions. The damping is critical in establishing the dynamics of the displacer. The ASCs for the EU had not been tested as the ASRG controller was being developed and therefore there was no data available for validation of the models. While this might change the predicted performance somewhat, the SDM is traditionally not used for performance predictions; rather, it is used for dynamic analyses and evaluation of transient response and stability issues. Detailed validation of the SDM models has not been found to impact stability analyses in the past.

As a first step LMSS is using Simplorer (Ansoft Corporation) to model the control algorithm and run it against the GRC ASC model. The Simplorer nonlinear ASC model was converted into a state variable linear Simplorer model that was used in to verify control loop design. This model has been converted into a Matlab Simulink (The Mathworks, Inc.) model that is used in the actual FPGA coding process in Mathworks Matlab (The Mathworks, Inc.) and Mentor Graphics Modelsim (Mentor Graphics Corporation).

Through the simulation process the algorithm has been analyzed for Stability, Control Range and Limitations, Transient Response, Redundancy Switching, Performance Margins, Performance Sensitivities, and the Control loop constants for PI hardware controllers.

Figure 5 shows the Matlab (The Mathworks, Inc.) behavioral model simulation of ASC startup and changes in control point and control method. Note the lack of sensitivity to the dc output voltage step changes. The synchronization is maintained during the stepped command changes and the transient response is well-behaved.

Figure 6 shows a set of simulation results that were run to determine if the controller could take two ASCs operating nonsynchronized and synchronize the two ASCs to the control frequency. The difference in acceleration of the ASC pistons was selected as the criteria for judging the performance of the system during synchronization. Recalling that $F=m * a$, it is obvious that acceleration is directly proportional to the vibration of the ASC at its operating frequency. As can be seen in the simulation results the peak difference in acceleration is over $3500 \mathrm{~m} / \mathrm{s}^{2}$ (or $3500 \mathrm{~N} / \mathrm{kg}$ ) and after synchronization is $40 \mathrm{~m} / \mathrm{s}^{2}$ $(40 \mathrm{~N} / \mathrm{kg})$. Synchronization is achieved in less than 5 cycles. The model predicts that this transient displacement will exceed the physical limits of the ASC.

The simulation to date has verified single ASC stable control for both open loop voltage control and closed loop position control. Dual ASC simulation has demonstrated stable synchronization, open loop voltage control, and closed loop peak position control. 


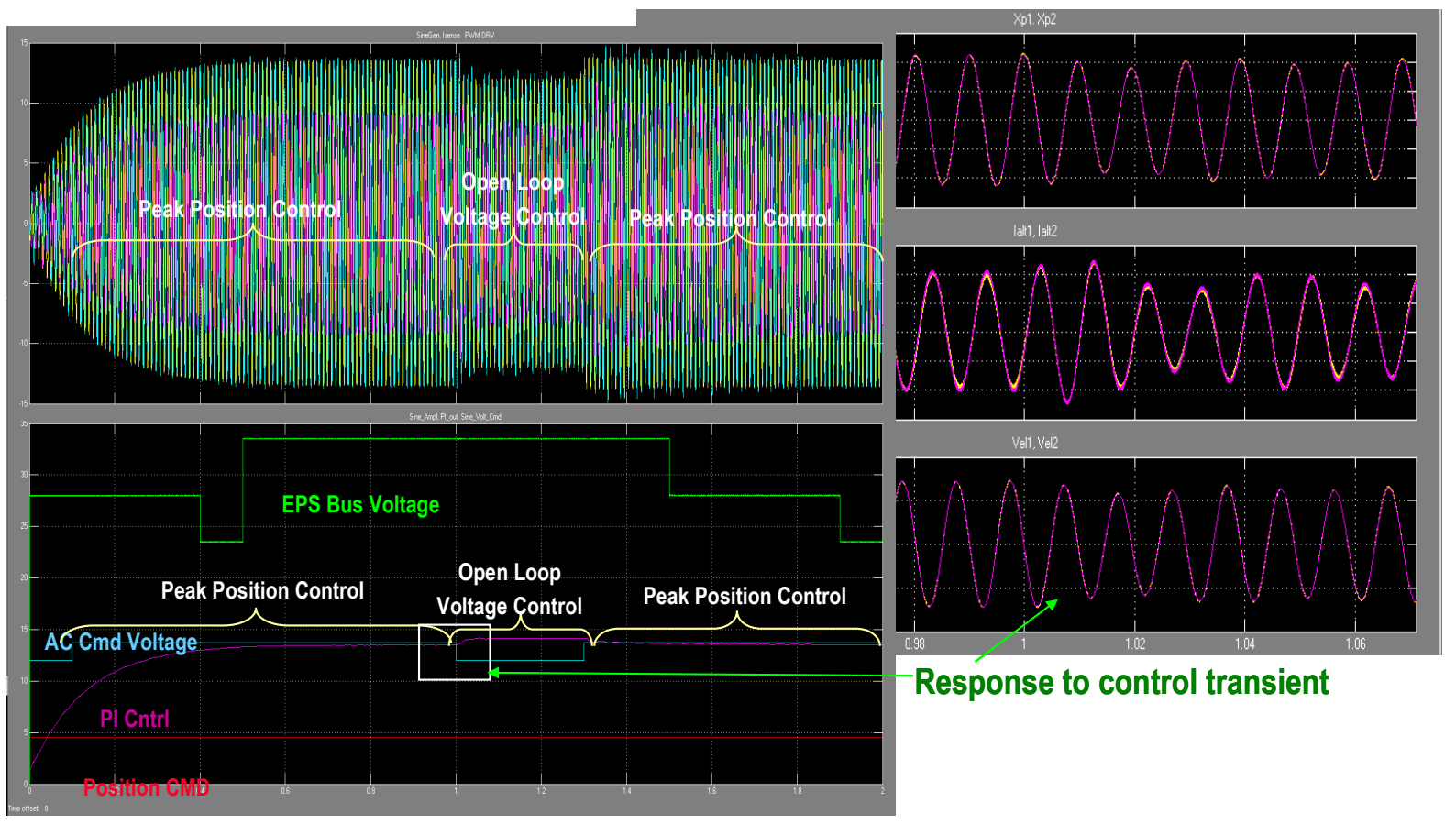

Figure 5.-ASC startup and step changes.

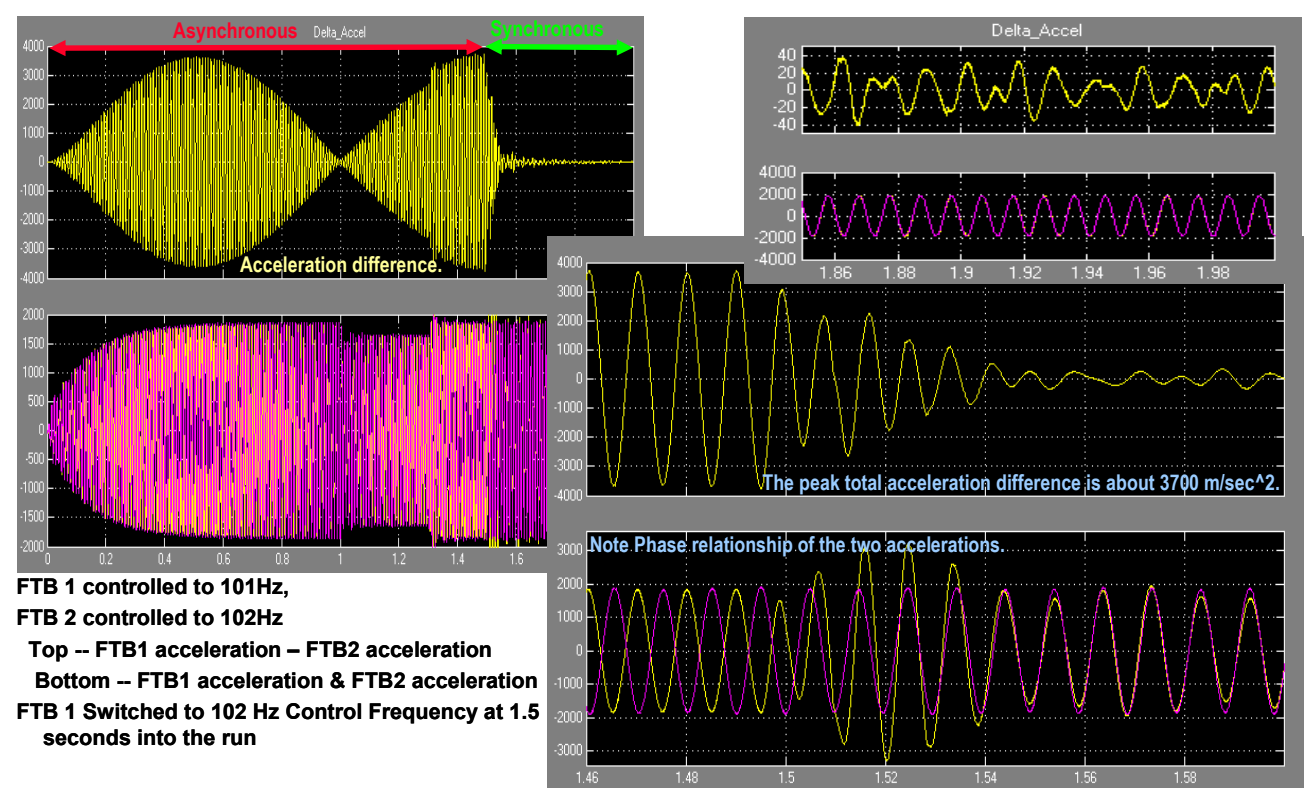

Figure 6.-Synchronization characteristics.

\section{Controller Testing}

The Control algorithm is being coded into an Actel re-programmable FPGA for the EU and a radhard Actel FPGA for flight. The algorithm coding effort is being done utilizing higher order language tools (Matlab/Simulink) instead of the manual intensive conversion of the algorithm to VHDL code. The tool set allows the algorithm to be completely tested and verified against the GRC linear ASC model at various stages throughout the coding cycle; including verifying the actual VHDL code. Figure 7 shows the design flow of the FPGA coding process. 


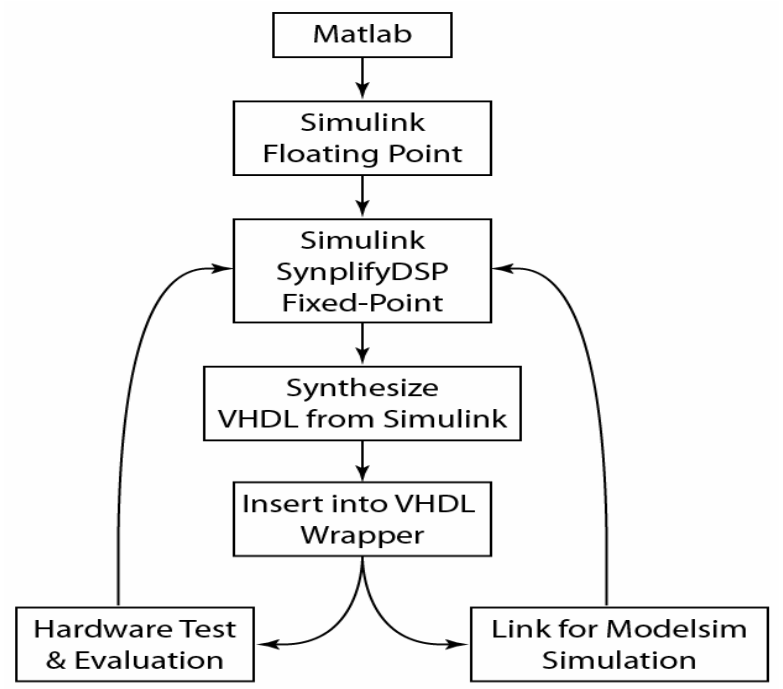

Figure 7.-FPGA coding flow.
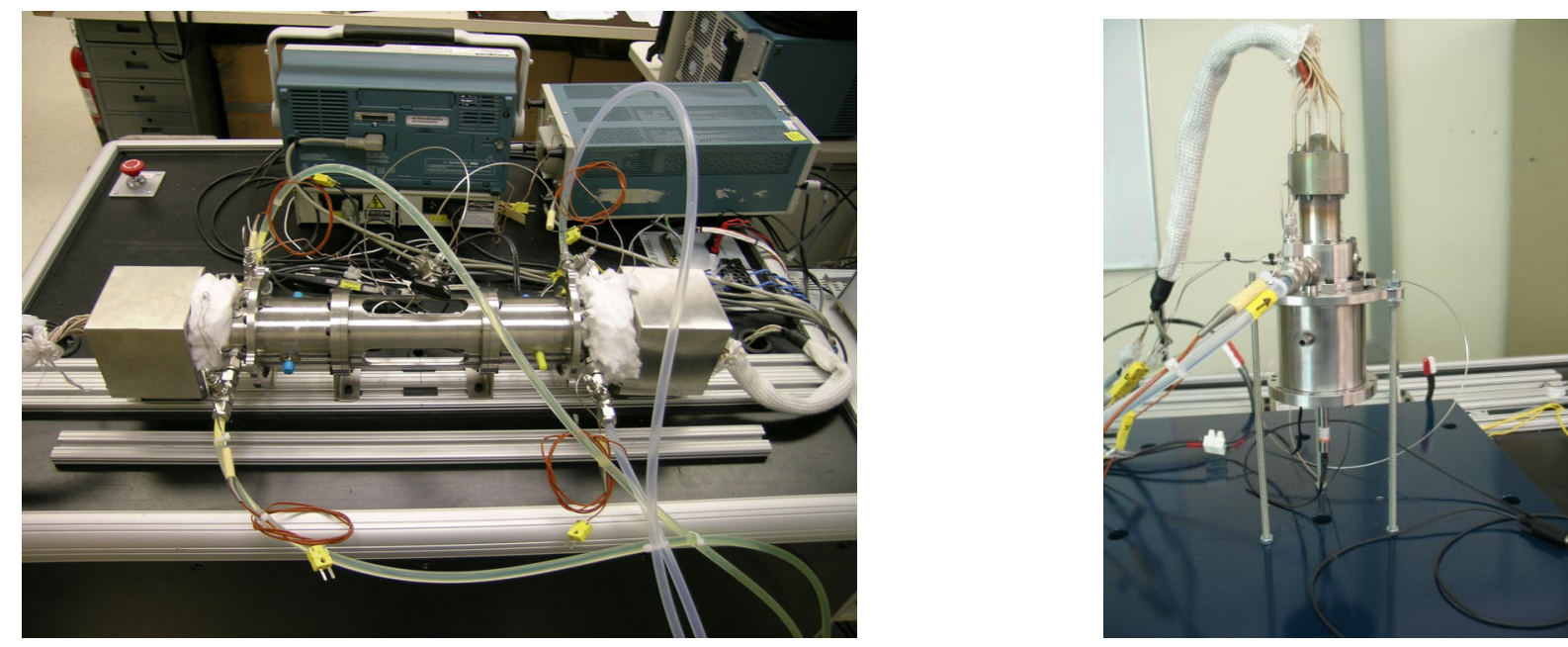

Figure 8.- Single and dual FTB set-up.

Two Sunpower FTB convertors are being used at LMSS to develop the algorithm and design of the EU controller. The FTBs are $80 \mathrm{~W}_{\mathrm{e}}$ convertors with an external, commercial FLDT. Two LMSS breadboard controllers are being utilized to control the FTB pair. For one convertor testing the FTB is setup in a vertical position, for two convertor testing the FTBs are set-up in a horizontally opposed configuration; both set-ups are shown in figure 8.

Single engine control with the LMSS design was achieved in February 2007. Control was achieved in an open-loop peak piston position control mode; there was no closed loop peak piston position feedback. The convertor was run at full power $\left(80 \mathrm{~W}_{\mathrm{e}}\right)$ and remained completely stable during the $4 \mathrm{hr}$ run. Dual convertor control was achieved one week after the single convertor control. Both convertors were run to full power $\left(80 \mathrm{~W}_{\mathrm{e}}\right)$ with complete frequency synchronization. This condition was maintained for $4 \mathrm{hr}$ and remained completely stable. Figure 9 shows the actual current measurements on synchronized FTB convertors. The currents show the ripple current induced by the PWM action of the controller. The bottom oscillogram is a sample of the alternator current when the FTB is operated using two Chroma ac power sources in master slave mode. 


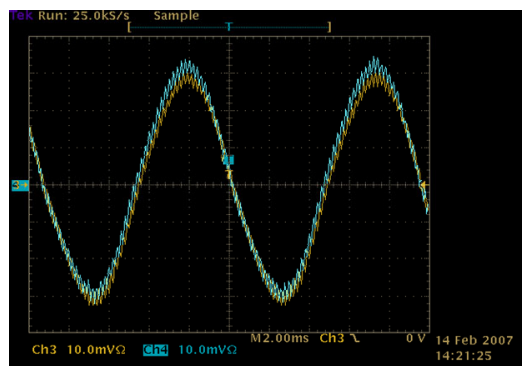

FTB1 Current w/Controller 1 FTB2 Current w/Controller 2 2A/div

\section{Synchronization of FTB ASC}

Alternator Currents With two Chroma AC Sources in Master Slave Configuration
Synchronization of FTB ASC

Alternator Currents

With Controller

Yellow Trace

FTB1 Current

Blue Trace

FTB2 Current

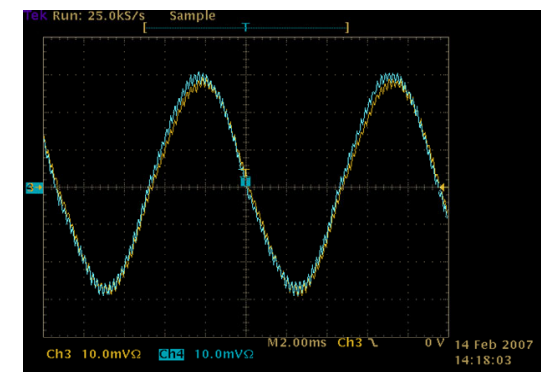

FTB1 Current w/Controller 1 FTB2 Current w/Controller 2 5A/div

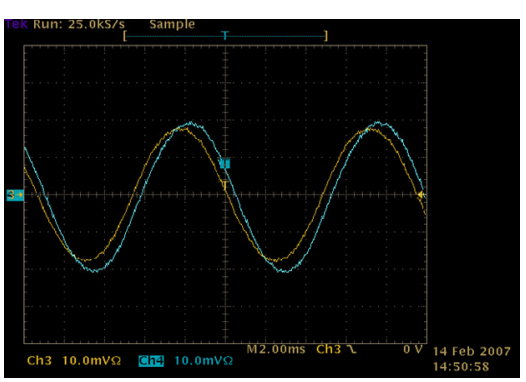

Yellow FTB1 Current w/Chroma 1 Blue FTB2 Current w/Chroma 2 2A/div

Figure 9.—Dual FTB test results.

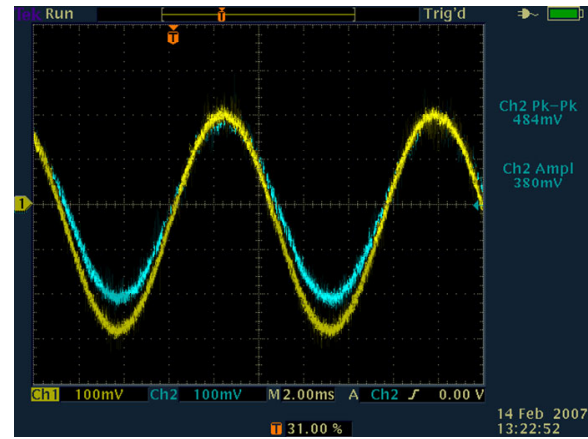

The FLDT output indicates the ASCs are synchronized with a small phase shift Oscillogram scaling, $100 \mathrm{mV} / \mathrm{div}$ FLDT Scaling, $0.2 \mathrm{~V} / \mathrm{mm}$

FLDT noise will reduce with new higher gain FLDT in new ASCs.

Analog and digital filtering will allow use of FLDT for peak piston control and limiting.
FTB1 FLDT Demod/Amp Output w/Controller 1 FTB2 FLDT Demod/Amp Output w/Controller 2 2A/div

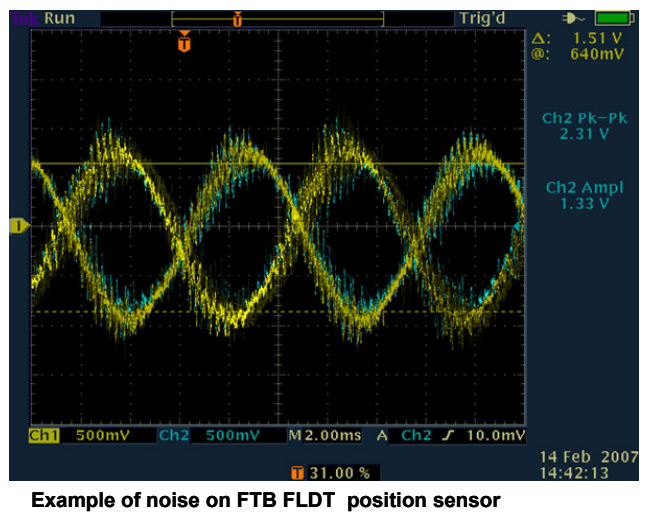

Oscillogram scaling, $500 \mathrm{mV} /$ div FLDT Scaling, $0.2 \mathrm{~V} / \mathrm{mm}$

Figure 10._FLDT synchronization test results.

Figure 10 shows the FLDT processor output voltage and the fact that the two FTBs are synchronized (top left). The noise susceptibility of the FLDT (bottom right) must be addressed and will be done with both analog and digital filtering.

Table 2 shows the capability that has been demonstrated by the ASRG controller to date. 
TABLE 2.-ASRG CONTROLLER DEMONSTRATED CAPABILITY

\begin{tabular}{|l|l|l|}
\hline \multicolumn{1}{|c|}{ Requirement } & \multicolumn{1}{|c|}{ Results } & \multicolumn{1}{|c|}{ Verified } \\
\hline Open loop piston position control & $\begin{array}{l}\text { FTB engines maintain commanded } \\
\text { alternator voltage to control peak } \\
\text { piston position }\end{array}$ & YES \\
\hline Closed loop piston position control & $\begin{array}{l}\text { Piston maintains peak position at the } \\
\text { peak position set point }\end{array}$ & YES \\
\hline Closed loop temperature control & $\begin{array}{l}\text { Peak Piston position is adjusted for } \\
\text { temperature }\end{array}$ & $\begin{array}{l}\text { Partially } \\
\text { Control loop has been verified, but } \\
\text { the entire system control will not be } \\
\text { verified until integration at the } \\
\text { generator level }\end{array}$ \\
\hline Synchronization & $\begin{array}{l}\text { Both FTBs synchronize to the } \\
\text { frequency set point and remain stable }\end{array}$ & YES \\
\hline Single fault tolerant & Done at EU box level & NO \\
\hline Command/telemetry & Done at EU box level & NO \\
\hline Output voltage 22 to $36 \mathrm{~V}$ & $\begin{array}{l}\text { Output voltage follows the bus while } \\
\text { maintaining stability of the FTBs } \\
\text { over the 22 to 36 V range }\end{array}$ & YES \\
\hline Efficiency $>93$ percent & Done at EU level & NO \\
\hline
\end{tabular}

\section{Current Status and Future Plans}

The EU controller cards are built and are undergoing functional testing at this time. The cards will be integrated into the EU chassis in mid-July. Full up EU functional and fault testing will continue until September 2007. Final algorithm development and testing is also continuing utilizing the breadboard units and a Sunpower ASC-1 convertor. The ASC-1 unit contains the final, internal FLDT design and a more flight-like thermal mass.

The EU controller unit is scheduled to be delivered for generator integration September 2007. The generator will go through a series of environmental tests: random vibration, thermal vacuum (TVac), EMI/EMC, and life testing. The EU controller will be controlling the two ASCs during TVac and vibration testing but will be separated from the generator and will not see the specific environment.

\section{Conclusion}

Challenges are still ahead in providing a robust ASRG that contains reliable fault protection switching and survival in the harsh environments of space. The ASRG program is meant to demonstrate that these challenges can be overcome. The successful demonstration of closed loop control and the synchronization of two ASCs utilizing the ASRG APFCs have provided a major step forward in the advancement of ASCs for space applications.

\section{References}

1. Leland, D., Priest, J., "Development of a Power Electronics Controller for the ASRG," STAIF 2007.

2. Holliday, E. and Keiter, D.E., "Sunpower Nondissipative Free Piston Stirling Engine Control Electronics for Dual-Opposed $130 \mathrm{~W}_{\mathrm{e}}$ Power System for Army Battery Charger" 4th International Energy Conversion Engineering Conference and Exhibit (IECEC) AIAA-2006-4188, San Diego, California, June 26-29, 2006.

3. Schreiber, J., "Developmental Considerations on the Free-Piston Stirling Power Convertor for Use in Space" 4th International Energy Conversion Engineering Conference and Exhibit (IECEC) AIAA2006-4015, San Diego, California, June 26-29, 2006.

4. Lewandowski, E. and Regan, T., "Overview of the GRC Stirling Convertor System Dynamic Model," 2nd International Energy Conversion Engineering Conference AIAA-2004-5671, Providence, Rhode Island, August 16-19, 2004. 


\begin{tabular}{|c|c|c|}
\hline \multicolumn{2}{|c|}{ REPORT DOCUMENTATION PAGE } & $\begin{array}{l}\text { Form Approved } \\
\text { OMB No. 0704-0188 }\end{array}$ \\
\hline \multicolumn{3}{|c|}{$\begin{array}{l}\text { The public reporting burden for this collection of information is estimated to average } 1 \text { hour per response, including the time for reviewing instructions, searching existing data sources, gathering and maintaining the } \\
\text { data needed, and completing and reviewing the collection of information. Send comments regarding this burden estimate or any other aspect of this collection of information, including suggestions for reducing this } \\
\text { burden, to Department of Defense, Washington Headquartrers Services, Directorate for Information Operations and Reports }(0704-0188) \text {, } 1215 \text { Jefferson Davis Highway, Suite } 1204 \text {, Arlington, VA } 22202-4302 \text {. } \\
\text { Respondents should be aware that notwithstanding any other provision of law, no person shall be subject to any penalty for failing to comply with a collection of information if it does not display a currently valid OM } \\
\text { control number. } \\
\text { PLEASE DO NOT RETURN YOUR FORM TO THE ABOVE ADDRESS. }\end{array}$} \\
\hline $\begin{array}{l}\text { 1. REPORT DATE (DD-MM-YYYY) } \\
01-02-2008\end{array}$ & $\begin{array}{l}\text { 2. REPORT TYPE } \\
\text { Technical Memorandum }\end{array}$ & 3. DATES COVERED (From - To) \\
\hline \multirow{3}{*}{\multicolumn{2}{|c|}{$\begin{array}{l}\text { 4. TITLE AND SUBTITLE } \\
\text { Development of a Power Electronics Controller for the Advanced Stirling Radioisotope } \\
\text { Generator }\end{array}$}} & 5a. CONTRACT NUMBER \\
\hline & & 5b. GRANT NUMBER \\
\hline & & 5c. PROGRAM ELEMENT NUMBER \\
\hline \multirow{3}{*}{\multicolumn{2}{|c|}{$\begin{array}{l}\text { 6. AUTHOR(S) } \\
\text { Leland, Douglas, K.; Priest, Joel, F.; Keiter, Douglas, E.; Schreiber, Jeffrey, G. }\end{array}$}} & 5d. PROJECT NUMBER \\
\hline & & 5e. TASK NUMBER \\
\hline & & $\begin{array}{l}\text { 5f. WORK UNIT NUMBER } \\
\text { WBS } 138494.04 .01 .01\end{array}$ \\
\hline \multicolumn{2}{|c|}{$\begin{array}{l}\text { 7. PERFORMING ORGANIZATION NAME(S) AND ADDRESS(ES) } \\
\text { National Aeronautics and Space Administration } \\
\text { John H. Glenn Research Center at Lewis Field } \\
\text { Cleveland, Ohio 44135-3191 }\end{array}$} & $\begin{array}{l}\text { 8. PERFORMING ORGANIZATION } \\
\text { REPORT NUMBER } \\
\text { E-16074 }\end{array}$ \\
\hline \multirow{2}{*}{\multicolumn{2}{|c|}{$\begin{array}{l}\text { 9. SPONSORING/MONITORING AGENCY NAME(S) AND ADDRESS(ES) } \\
\text { National Aeronautics and Space Administration } \\
\text { Washington, DC 20546-0001 }\end{array}$}} & $\begin{array}{l}\text { 10. SPONSORING/MONITORS } \\
\text { ACRONYM(S) } \\
\text { NASA }\end{array}$ \\
\hline & & $\begin{array}{l}\text { 11. SPONSORING/MONITORING } \\
\text { REPORT NUMBER } \\
\text { NASA/TM-2008-215031; AIAA-2007- } \\
4737\end{array}$ \\
\hline \multicolumn{3}{|c|}{$\begin{array}{l}\text { 12. DISTRIBUTION/AVAILABILITY STATEMENT } \\
\text { Unclassified-Unlimited } \\
\text { Subject Category: } 20 \\
\text { Available electronically at http://gltrs.grc.nasa.gov } \\
\text { This publication is available from the NASA Center for AeroSpace Information, 301-621-0390 }\end{array}$} \\
\hline
\end{tabular}

\section{SUPPLEMENTARY NOTES}

\section{ABSTRACT}

Under a U.S. Department of Energy program for radioisotope power systems, Lockheed Martin is developing an Engineering Unit of the Advanced Stirling Radioisotope Generator (ASRG). This is an advanced version of the previously reported SRG110 generator. The ASRG uses Advanced Stirling Convertors (ASCs) developed by Sunpower Incorporated under a NASA Research Announcement contract. The ASRG makes use of a Stirling controller based on power electronics that eliminates the tuning capacitors. The power electronics controller synchronizes dual-opposed convertors and maintains a fixed frequency operating point. The controller is single-fault tolerant and uses highfrequency pulse width modulation to create the sinusoidal currents that are nearly in phase with the piston velocity, eliminating the need for large series tuning capacitors. Sunpower supports this effort through an extension of their controller development intended for other applications. Glenn Research Center (GRC) supports this effort through system dynamic modeling, analysis and test support. The ASRG design arrived at a new baseline based on a system-level trade study and extensive feedback from mission planners on the necessity of single-fault tolerance. This paper presents the baseline design with an emphasis on the power electronics controller detailed design concept that will meet space mission requirements including single fault tolerance.

\section{SUBJECT TERMS}

Free-piston Stirling; Radioisotope

\begin{tabular}{|c|c|c|c|c|c|}
\hline \multicolumn{3}{|c|}{ 16. SECURITY CLASSIFICATION OF: } & \multirow{2}{*}{$\begin{array}{l}\text { 17. LIMITATION OF } \\
\text { ABSTRACT } \\
\text { UU }\end{array}$} & \multirow{2}{*}{$\begin{array}{l}\text { 18. NUMBER } \\
\text { OF } \\
\text { PAGES } \\
18\end{array}$} & \multirow{2}{*}{$\begin{array}{l}\text { 19a. NAME OF RESPONSIBLE PERSON } \\
\text { STI Help Desk (email:help@sti.nasa.gov) } \\
\text { 19b. TELEPHONE NUMBER (include area code) } \\
\text { 301-621-0390 }\end{array}$} \\
\hline $\begin{array}{l}\text { a. REPORT } \\
U\end{array}$ & $\begin{array}{l}\text { b. ABSTRACT } \\
U\end{array}$ & $\begin{array}{l}\text { c. THIS } \\
\text { PAGE } \\
\text { U }\end{array}$ & & & \\
\hline
\end{tabular}



